\title{
APT Generation of Long-Lived Radionuclides to Include Greater Than Class C Low-Level Radioactive Waste Requiring Special Disposal Considerations
}

by

R. W. Reynolds

Westinghouse Savannah River Company

Savannah River Site

Aiken, South Carolina 29808

J. England

A document prepared for PUBLIC READING ROOM - ACCELERATOR PRODUCTION OF TRITIUM ENVIRONMENTAL IMPACT STATEMENT REFERENCES - APT EIS REFERENCE at , , from - :

\section{DOE Contract No. DE-AC09-96SR18500}

This paper was prepared in connection with work done under the above contract number with the U.S. Department of Energy. By acceptance of this paper, the publisher and/or recipient acknowledges the U.S. Government's right to retain a nonexclusive, royalty-free license in and to any copyright covering this paper, along with the right to reproduce and to authorize others to reproduce all or part of the copyrighted paper. 


\section{DISCLADMER}

Portions of this document may be illegibie in electronic image products. Images are produced from the best available original document. 


\section{DISCLAIMER}

This report was prepared as an account of work sponsored by an agency of the United States Government. Neither the United States Government nor any agency thereof, nor any of their employees, makes any warranty, express or implied, or assumes any legal liability or responsibility for the accuracy, completeness, or usefulness of any information, apparatus, product, or process disclosed, or represents that its use would not infringe privately owned rights. Reference herein to any specific commercial product, process, or service by trade name, trademark, manufacturer, or otherwise does not necessarily constitute or imply its endorsement, recommendation, or favoring by the United States Government or any agency thereof. The views and opinions of authors expressed herein do not necessarily state or reflect those of the United States Government or any agency thereof.

This report has been reproduced directly from the best available copy.

Available to DOE and DOE contractors from the Office of Scientific and Technical Information, P. O. Box 62, Oak Ridge, TN 37831; prices available from (423) 576-8401.

Available to the public from the National Technical Information Service, U. S. Department of Commerce, 5285 Port Royal Road, Springfield, VA 22161. 
WSAC-TR-97-0259

Rev 0

APT Waste Management Team

White Paper

on

APT Generation of Long Lived Radionuclides

to Include Greater Than Class C

Low Level Radioactive Waste

Requiring Special Disposal Considerations

August 20, 1997

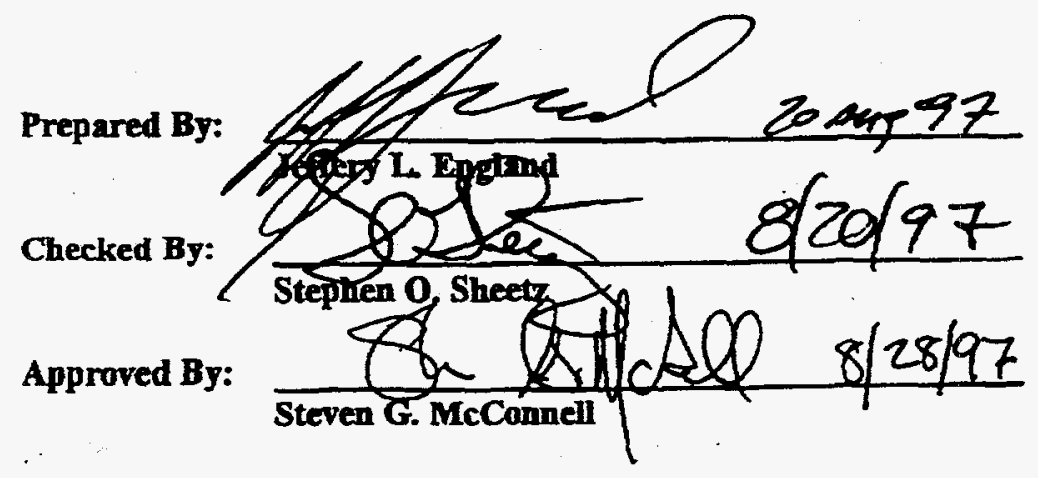


APT Generation of Long Lived Radionuclides to Include GTCC Low Level Radioactive Waste Requiring Special Disposal Considerations

WSRC-TR-97-0259? Rev 0

\subsection{Introduction}

The Accelerator Production of Tritium (APT) Facility will generate radioactive waste during routine operations of the plant. All of the waste generated will be Low Level Radioactive Waste (LLRW) or Mixed Low Level Waste (MLLW). Some APT wastes to be generated contain combinations of short lived and long lived radionuclides exceeding the current Waste Acceptance Criteria (WAC) of all Department Of Energy (DOE) disposal locations. Some of the wastes would be classified Greater Than Class C (GTCC) LLRW under the Nuclear Regulatory Commission. The Nuclear Regulatory Commission (NRC) specifies a geologic repository for GTCC wastes. The Department Of Energy (DOE) specifies in 5820.2A geologic disposal shall comply with both Nuclear Regulatory Commission regulations and EPA standards.

\subsection{Classification of Low Level Radioactive Waste}

Determination of the classification of radioactive waste (LLRW) involves two considerations. First, consideration is given to the concentration of long-lived radionuclides (and their shorter-lived precursors) whose potential hazard will persist long after such precautions as institutional controls, improved waste form, and deeper disposal have ceased to be effective. These precautions only delay the time when long-lived radionuclides could cause exposures. In addition, the magnitude of the potential dose is limited by the concentration and availability of the radionuclide at the time of exposure. Second, consideration must be given to the concentration of shorter-lived radionuclides where requirements on institutional controls, waste form, and disposal methods are effective. For classification of APT LLRW containing mixtures of radionuclides listed in Table 1 , the total concentration shall be determined by the sum of fractions rule.

TABLE 1

Radionuclides Applicable to APT

\begin{tabular}{|l|r|}
\hline Radionuclide & Ci per $\mathbf{M}^{\mathbf{3}}$ \\
\hline C-14 & 8 \\
\hline C-14 in activated metal & 80 \\
\hline Ni-59 in activated metal & 220 \\
\hline Nb-94 in activated metal & 0.2 \\
\hline Tc-99 & 3 \\
\hline I-129 & 0.08 \\
\hline
\end{tabular}

If APT radioactive waste does not contain any of the radionuclides listed in Table 1, APT LLRW classification shall be determined by short-lived radionuclides on the concentrations shown in Table 2 . If APT radioactive waste does not contain any nuclides 
APT Generation of Long Lived Radionuclides to Include GTCC Low Level Radioactive Waste Requiring Special Disposal Considerations

WSRC-TR-97-0251? Rev 0

listed in either Table 1 or 2 , it is Class $\mathrm{A}$.

If the concentration does not exceed the value in Column 1, the waste is Class $A$. If the concentration exceeds the value in Column 1, but does not exceed the value in Column 2, the waste is Class B. If the concentration exceeds the value in Column 2, but does not exceed the value in Column 3, the waste is Class $C$. If the concentration exceeds the value in Column 3, the waste is not generally acceptable for near-surface disposal. For wastes containing mixtures of the nuclides listed in Table 2 , the total concentration shall be determined by the sum of fractions rule.

TABLE 2

Radionuclides Applicable to APT

\begin{tabular}{|l|r|r|r|}
\hline Radionuclide & $\begin{array}{c}\text { Ci per } \mathbf{~ M}^{\mathbf{3}} \\
\text { Col 1 }\end{array}$ & $\begin{array}{c}\text { Ci per } \mathbf{M}^{\mathbf{3}} \\
\text { Col 2 }\end{array}$ & $\begin{array}{c}\mathbf{C i ~ p e r ~}^{\mathbf{3}} \\
\text { Col 3 }\end{array}$ \\
\hline $\begin{array}{l}\text { Total of all nuclides with less than 5 } \\
\text { year half-life. }\end{array}$ & 700 & $(\{1\})$ & $(\{1\})$ \\
\hline H-3 & 40 & $(\{1\})$ & $(\{1\})$ \\
\hline Co-60 & 700 & $(\{1\})$ & $(\{1\})$ \\
\hline Ni-63 & 3.5 & 70 & 700 \\
\hline Ni-63 in activated metal & 35 & 700 & 7000 \\
\hline Sr-90 & 0.04 & 150 & 7000 \\
\hline Cs-137 & 1 & 44 & 4600 \\
\hline
\end{tabular}

\{1\} There are no limits established for these radionuclides in Class B or C wastes. Practical considerations such as the effects of external radiation and internal heat generation on transportation, handling, and disposal will limit the concentrations for these wastes. These wastes shall be Class $B$ unless the concentrations of other nuclides in Table 2 determine the waste to the Class $\mathrm{C}$ independent of these nuclides.

Most APT LLRW contains a mixture of radionuclides, some listed in Table 1, and some listed in Table 2, classification shall be determined as follows:

(i) If the concentration of a nuclide listed in Table 1 does not exceed 0.1 times the value listed in Table 1, the class shall be determined by the concentration of nuclides listed in Table 2.

(ii) If the concentration of a nuclide listed in Table 1 exceeds 0.1 times the value listed in Table 1 but does not exceed the value in Table 1 , the waste shall be Class $C$, provided the concentration of nuclides listed in Table 2 does not exceed the value 
APT Generation of Long Lived Radionuclides to Include GTCC Low Level Radioactive Waste Requiring Special Disposal Considerations

WSRC-TR-97-025\$, Rev 0

August 20, 1997

shown in Column 3 of Table 2.

For classification of wastes with radionuclides other than those listed in Tables 1 and 2 it is fairly simple. If a APT LLRW stream does not contain any nuclides listed in either Table 1 or 2 , it is Class A.

Since most APT LLRW contains a mixture of radionuclides the sum of the fractions rule will apply. The sum of the fractions rule for mixtures of radionuclides is as follows:

For determining classification for waste containing a mixture of radionuclides, it is necessary to determine the sum of fractions by dividing each nuclide's concentration by the appropriate limit and adding the resulting values. The appropriate limits must all be taken from the same column of the same table. The sum of the fractions for the column must be less than 1.0 if the waste class is to be determined by that column.

Example:

A waste contains $\mathrm{Sr}-90$ in a concentration of $50 \mathrm{Ci} / \mathrm{m} 3$. and $\mathrm{Cs}-137$ in a concentration of $22 \mathrm{Ci} / \mathrm{m} 3$. Since the concentrations both exceed the values in Column 1, Table 2, they must be compared to Column 2 values. For Sr-90 fraction $50 / 150=0.33$; for $C s-137$ fraction, $22 / 44=0.5$; the sum of the fractions $=0.83$. Since the sum is less than 1.0 , the waste is Class B.

Greater Than Class C (GTCC) waste is not generally acceptable for near-surface disposal. It is waste where waste form and disposal methods are different, and in general more stringent, than those specified for Class $C$ waste. Such waste must be disposed of in a geologic repository as defined in 10 CFR 60.

\subsection{Concentration of Radionuclide Determination For Low Level Radioactive Waste}

The concentration of a radionuclide may be determined by indirect methods such as use of scaling factors relating the inferred concentration of one radionuclide to another one that is measured, or radionuclide material accountability, if there is reasonable assurance that the indirect methods can be correlated with actual measurements. The concentration of a radionuclide may be averaged over the volume of the waste, or weight of the waste if the units are expressed as nanocuries per gram.

\subsection{APT Generated Greater Than Class C Low Level Radioactive Waste}


APT Generation of Long Lived Radionuclides to Include GTCC Low Level Radioactive Waste Requiring Special Disposal Conşiderations

WSRC-TR-97-0259, Rev 0

August 20, 1997

Following this guidance there are several waste streams of APT LLRWs to be generated exceeding the regulatory guidance of $10 \mathrm{CFR}$ 61.55 GTCC criteria and/or exceeding the WACs of potential DOE disposal locations (reference 7.5). These wastes include:

1. T/B Cavity Vessel Window Module

2. Tungsten Neutron Source Modules

3. Row 1 and Downstream Lead Modules

These modules exceed WACs on either an individual radionuclide or by the sum of fractions (see section 2.0).

Some of these radionuclides can be reduced by product substitution (taking out niobium from Inconel and other stainless steels) and can be averaged out by the volume of the waste (see section 3.0). Even with these actions, and the material substitutions are the right technical thing to do and may increase the acceptability of the waste to a disposal unit, it is unlikely the waste will exit the category of GTCC or still meet current WACs.

These wastes will require storage at SRS and then shipment by DOT Type B Shipping Casks (to any facility off the site boundary of SRS) to a disposal facility capable of handling these wastes.

The estimated problematic LLRW to be generated per year is listed in Table 3.

Table 3

APT Annual Estimated Problematic LLRW

\begin{tabular}{|c|r|r|}
\hline Waste Stream & Volume & Mass \\
\hline Lead Modules & $10 \mathrm{~m}^{3}$ & $37,000 \mathrm{~kg}$ \\
\hline Tungsten & $1 \mathrm{~m}^{3}$ & $1100 \mathrm{~kg}$ \\
\hline Window Modules & $0.5 \mathrm{~m}^{3}$ & $100 \mathrm{~kg}$ \\
\hline Cavity Vessel Steel and Aluminum & $1 \mathrm{~m}^{3}$ & $500 \mathrm{~kg}$ \\
\hline
\end{tabular}

Table 4

APT Estimated GTCC Radionuclide Concentrations (Ci per $\mathrm{M}^{3}$ ) Based on Cinder $901700 \mathrm{MeV}$ Data for 274 days Irradiation and 2 years cooling

\begin{tabular}{|l|r|r|r|r|}
\hline Radionuclide & Limits Ci per $\mathbf{M}^{3}$ & $\begin{array}{l}\text { Window } \\
\text { Module }\end{array}$ & $\begin{array}{l}\text { Tungsten } \\
\text { Neutron } \\
\text { Source }\end{array}$ & Lead Modules \\
\hline C-14 in activated metal & 80 & 10.3 & 77.6 & 3.39 \\
\hline Co-60 & $(\{1\})$ & 166,000 & 80,000 & 83.0 \\
\hline Ni-59 in activated metal & 220 & 50.6 & 71.4 & 0.004 \\
\hline Ni-63 in activated metal & 7000 & 3680 & 8130 & 11.8 \\
\hline Sr-90 & 7000 & 0.002 & 0.037 & 31.6 \\
\hline Nb-94 in activated metal & 0.2 & 18.7 & 10.0 & 0.03 \\
\hline Tc-99 & 3 & 0.24 & 3.27 & 0.007 \\
\hline
\end{tabular}


APT Generation of Long Lived Radionuclides to Include GTCC Low Level Radioactive Waste Requiring Special Disposal Considerations WSRC-TR-97-0258, Rev 0

August 20, 1997

\begin{tabular}{|l|r|r|r|r|}
\hline $\mathrm{I}-129$ & 0.08 & N/A & $4.07 \mathrm{E}-7$ & $9.55 \mathrm{E}-6$ \\
\hline $\mathrm{Cs}-137$ & 4600 & N/A & $1.74 \mathrm{E}-4$ & $6.85 \mathrm{E}-4$ \\
\hline
\end{tabular}

$\{1\}$

There are no limits established for these radionuclides in Class B or C wastes. Practical considerations such as the effects of external radiation and internal heat generation on transportation, handling, and disposal will limit the concentrations for these wastes. These wastes shall be Class B unless the concentrations of other nuclides in Table 2 determine the waste to the Class $\mathrm{C}$ independent of these nuclides.

DOE Order $5820.2 \mathrm{a}$ requires a document forecasting waste to be shipped by generators to off-site disposal facilities. It also requires reports justifying on-site disposal of waste exceeding Class C limits. GTCC disposal cases anticipated by a facility should be forecast.

\subsection{APT GTCC Low Level Radioactive Waste Disposal Options}

There are several potential disposal options possible and each require more investigation. The most likely options are Yucca Mountain, Hanford, Nevada Test Site (NTS), and Savannah River Site (SRS). Currently there is no agreed to path forward to permanent disposal of GTCC wastes in the DOE complex. Uncertainty currently exists regarding disposition pathways resulting from similarities in the definition of GTCC waste, Special Case waste, and non-fuel bearing components of Spent Nuclear Fuel. DOE's strategy for management and disposal of GTCC waste was presented to Stakeholders in April 1995. Co-disposal of GTCC wastes with other waste types is being considered as an option. At the time of this discussion the inventory of waste defined as GTCC was expected to be approximately $1,500 \mathrm{~m}^{3}$ by 2035 . It was concluded the volume of GTCC LLRW should not pose a significant management problem from a scientific or technical standpoint. At the time of this stakeholder meeting the projected volume of GTCC LLRW was considered small enough to indicate a dedicated disposal facility for this waste may not be justified. Factoring in APT GTCC waste at $1,000 \mathrm{~m}^{3}$ estimated for 40 years operation and Decommissioning it should not change this position.

DOE Order 5820.2a provides the following guidance on DOE waste containing accelerator produced radioactive material as defined by the Atomic Energy Act shall be stored and/or disposed of consistent with the requirements of the residual radioactive material guidelines contained in 40 CFR 192. Small volumes of DOE waste containing accelerator produced radioactive material may be managed as low-level waste. All DOE waste containing accelerator produced radioactive material mixed with the Resource Conservation and Recovery Act hazardous chemicals shall be managed as hazardous waste under the Resource Conservation and Recovery Act. Accelerator produced radioactive material mixed with the Resource Conservation and Recovery Act hazardous 
APT Generation of Long Lived Radionuclides to Include GTCC Low Level Radioactive Waste Requiring Special Disposal Considerations

WSRC-TR-97-0251, ${ }^{9}$ Rev 0

chemicals, shall be managed consistent with both the Resource Conservation and Recovery Act and 40 CFR Part 192.

DOE Order 5820.2a states the Assistant Secretary for Nuclear Energy (NE-1) is responsible for managing any greater than Class $\mathrm{C}$ low-level waste accepted by the DOE for disposal in cooperation with Assistant Sec Secretary for Defense Programs (DP-1). Disposition of waste designated as greater-than-class $\mathrm{C}$ must be handled as special cases. Disposal systems for such waste must be justified by a specific performance assessment through the National Environmental Policy Act (NEPA) process and with the concurrence of DP-12 for all DP-1 disposal facilities and of NE-20 for those disposal facilities under the cognizance of NE-1.

\subsection{High Level Waste Repository}

There are technical issues to be resolved with a High Level Waste Repository disposal option. Yucca Mountain is currently the option being considered for this repository.

1. Yucca Mountain does not expect the high wattage waste APT will generate from its vast inventory of short life radionuclides. Current information indicates this may not be a problem due to the high wattage waste being prepared for shipment to Yucca Mountain (Spent Nuclear Fuel, borosilicate glass w/High Level Waste, etc.)

2. Yucca Mountain is not currently planning on being permitted for RCRA disposal. The largest volume of APT GTCC waste is classified as mixed waste.

3. Yucca Mountain Waste Acceptance Criteria (WAC) must be evaluated and systems installed in APT to get waste in conformance with the WAC.

4. Yucca Mountain is the only "geologic repository" in the DOE complex at this time.

5. Yucca Mountain PA probably addresses all the long lived isotopes generated by an accelerator activity.

\subsection{Nevada Test Site}

There are several issues to be resolved with a Nevada Test Site (NTS) disposal option. 
APT Generation of Long Lived Radionuclides to Include GTCC Low Level Radioactive Waste Requiring Special Disposal Considerations

WSRC-TR-97-0250, ${ }^{4}$ Rev 0

August 20, 1997

1. NTS does not expect the high wattage waste APT will generate from its vast inventory of short life radionuclides. Probably not a real problem

since

they are not using a vault system.

2. APT will be shipping mixed waste for permanent disposal at NTS. NTS is not currently permitted for off-site mixed waste.

3. NTS PA must be modified to evaluate APT waste and nuclides.

4. The NTS WAC does not exclude the possibility of GTCC waste disposal and discusses their path forward to work the issue of GTCC disposal.

5. Our waste exceeds the current NTS WAC for C-14, Sr-90, and Bi207 as a minimum. Not all of our problematic radionuclides are addressed by the NTS WAC (e.g. Nb-94)

\subsection{Savannah River Site}

There are many issues to be resolved with a SRS disposal option.

1. SRS does not expect the high wattage waste APT will generate from its vast inventory of short life radionuclides. There is currently a 0.1 watt per cubic foot limit in the E-Area Vault WAC.

2. SRS is not permitted nor is it expected to be permitted for mixed waste permanent disposal.

3. SRS PA must be modified to evaluate APT waste and nuclides. APT Waste Management Team and Savannah River Technology Center completed a "back of the envelope" look at the PA and determined it is feasible to pursue SRS disposal for most if not all of these waste streams.

4. Our waste exceeds the current SRS WAC for $\mathrm{H}-3, \mathrm{C}-14, \mathrm{Al}-26, \mathrm{Ni}-59$, Se-79, Tc-99, and I-129 as a minimum. Not all of our problematic radionuclides are addressed by the SRS WAC (e.g. Nb-94).

\section{$5.4 \quad$ Hanford Site}

There are several issues to be resolved with a Hanford disposal option.

1. Hanford does not expect the high wattage waste APT will generate from its vast inventory of short life radionuclides. Probably not a real problem 
APT Generation of Long Lived Radionuclides to Include GTCC Low Level Radioactive Waste Requiring Special Disposal Considerations

WSRC-TR-97-0258, TRev 0

since they are not using a vault system.

2. APT will be shipping mixed waste for permanent disposal at Hanford. Hanford is not currently permitted for off-site mixed waste disposal.

3. Hanford PA must be modified to evaluate APT waste and nuclides.

4. Our waste exceeds the current Hanford WAC for C-14, Cl-36, Nb-94, Mo-93, and Eu-150 as a minimum. 
APT Generation of Long Lived Radionuclides to Include GTCC Low Level Radioactive Waste Requiring Special Disposal Considerations

WSRC-TR-97-025, Rev 0

August 20, 1997

\subsection{Minimum Packaging For Disposal of Low Level Radioactive Waste}

APT LLRW shall have to meet, at a minimum, these packaging requirements for disposal. Any mixed waste will also have to meet additional RCRA disposal requirements. Any DOT requirements for off-site shipment are also in addition to these minimum requirements.

(i) Waste must not be packaged for disposal in cardboard or fiberboard boxes.

(ii) Liquid waste must be solidified or packaged in sufficient absorbent material to absorb twice the volume of the liquid.

(iii) Solid waste containing liquid shall contain as little free standing and noncorrosive liquid as is reasonably achievable, but in no case shall the liquid exceed $1 \%$ of the volume.

(iv) Waste must not be readily capable of detonation or of explosive decomposition or reaction at normal pressures and temperatures, or of explosive reaction with water.

(v) Waste must not contain, or be capable of generating, quantities of toxic gases, vapors, or fumes harmful to persons transporting, handling, or disposing of the waste.

(vi) Waste must not be pyrophoric. Pyrophoric materials contained in waste shall be treated, prepared, and packaged to be nonflammable.

(vii) Waste containing hazardous, biological, pathogenic, or infectious material must be treated to reduce to the maximum extent practicable the potential hazard from the non-radiological materials.

The requirements are intended to provide stability of the waste. Stability is intended to ensure the waste does not structurally degrade and affect overall stability of the site through slumping, collapse, or other failure of the disposal unit and thereby lead to water infiltration. Stability is also a factor in limiting exposure to an inadvertent intruder, since it provides a recognizable and nondispersible waste.

Waste must have structural stability. A structurally stable waste form will generally maintain its physical dimensions and its form, under the expected disposal conditions such as weight of overburden and compaction equipment, the presence of moisture, and microbial activity, and internal factors such as radiation effects and chemical changes. Structural stability can be provided by the waste form itself, processing the waste to a 
APT Generation of Long Lived Radionuclides to Include GTCC Low Level Radioactive Waste Requiring Special Disposal Considerations

WSRC-TR-97-0251? Rev 0

August 20, 1997

stable form, or placing the waste in a disposal container or structure providing stability after disposal.

Liquid wastes, or wastes containing liquid, must be converted into a form containing as little free standing and noncorrosive liquid as is reasonably achievable, but in no case shall the liquid exceed $1 \%$ of the volume of the waste when the waste is in a disposal container designed to ensure stability, or $0.5 \%$ of the volume of the waste for waste processed to a stable form.

Void spaces within the waste and between the waste and its package must be reduced to the extent practicable.

\subsection{Definitions}

Low-Level Waste. Waste that contains radioactivity and is not classified as high-level waste, transuranic waste, or spent nuclear fuel or $11 \mathrm{e}(2)$ byproduct material as defined by this Order. Test specimens of fissionable material irradiated for research and development only, and not for the production of power or plutonium, may be classified as low-level waste, provided the concentration of transuranic is less than $100 \mathrm{nCi} / \mathrm{g}$.

Mixed Waste. Waste containing both radioactive and hazardous components as defined by the Atomic Energy Act and the Resource Conservation and Recovery Act, respectively.

Naturally Occurring and Accelerator Produced Radioactive Material. Any radioactive material that can be considered naturally occurring and is not source, special nuclear, or byproduct material or that is produced in a charged particle accelerator.

Near Surface Disposal. Disposal in the upper 30 meters of the earth's surface, (e.g. shallow land burial).

Performance Assessment. A systematic analysis of the potential risks posed by waste management systems to the public and environment, and a comparison of those risks to established performance objectives.

Radioactive Waste. Solid, liquid, or gaseous material that contains radionuclides regulated under the Atomic Energy Act of 1954, as amended and of negligible economic value considering costs of recovery.

Repository. A facility for the permanent deep geologic disposal of High Level or Transuranic Waste. 
APT Generation of Long Lived Radionuclides to Include GTCC Low Level Radioactive Waste Requiring Special Disposal Considerations

WSRC-TR-97-025, ${ }^{\text {Rev } 0}$

Storage. Retrievable retention of waste pending disposal.

Storage Facility. Land area, structures, and equipment used for the storage of waste.

Storage Unit. A discrete part of the storage facility in which waste is stored.

Treatment. Any method, technique, or process designed to change the physical or chemical character of waste to render it less hazardous, safer to transport, store or dispose of, or reduced in volume.

Treatment Facility. The specific area of land, structures, and equipment dedicated to waste treatment and related activities.

Waste Container. A receptacle for waste, including any liner or shielding material that is intended to accompany the waste in disposal.

Waste Management. The planning, coordination, and direction of those functions related to generation, handling, treatment, storage, transportation, and disposal of waste, as well as associated surveillance and maintenance activities.

Waste Package. The waste, waste container, and any absorbent intended for disposal as a unit. In the case of surface contaminated, damaged, leaking, or breached waste packages, any overpack shall be considered the waste container, and the original container shall be considered part of the waste.

\subsection{References}

\subsection{CFR 61.55}

$7.2 \quad 10$ CFR 61.56

$7.3 \quad 5820.2 \mathrm{~A}$

7.4 Nevada Test Site WAC

7.5 Ades, M.J., Preliminary Disposal Analysis for APT Waste (U), May 19, 1997, SWD-RDE-97-0008 